\title{
Baseline of the Use of Solar Irrigation Pump in the Niayes Area in Senegal
}

\author{
Aminata Sarr ${ }^{1,2}$, Lamine Diop ${ }^{1}$, Ibrahima Diatta ${ }^{3}$, Yaye Deffa Wane ${ }^{1}$, Ansouma Bodian ${ }^{4}$, \\ Sidy Mouhamed Seck ${ }^{3}$, Luciano Mateos ${ }^{5}$, Nicola Lamaddalena ${ }^{2}$
}

\author{
${ }^{1}$ Faculty of Agronomic Sciences, Aquaculture and Food Technology, Gaston Berger University, Saint Louis, Senegal \\ ${ }^{2}$ Irrigated Agriculture, Mediterranean Agronomic Institute of Bari (CIHEAM BARI), Bari, Italy \\ ${ }^{3}$ Interdisciplinary Research Group in Support of Regional Planning and Local Development, Gaston Berger University, \\ Saint Louis, Senegal \\ ${ }^{4}$ Faculty of Arts and Humanities, Gaston Berger University, Saint Louis, Senegal \\ ${ }^{5}$ Institute for Sustainable Agriculture, CSIC, Córdoba, Spain \\ Email: *lamine.diop@ugb.edu.sn
}

How to cite this paper: Sarr, A., Diop, L., Diatta, I., Wane, Y.D., Bodian, A., Seck, S.M., Mateos, L. and Lamaddalena, N. (2021) Baseline of the Use of Solar Irrigation Pump in the Niayes Area in Senegal. Natural Resources, 12, 125-146.

https://doi.org/10.4236/nr.2021.125010

Received: April 1, 2021

Accepted: May 28, 2021

Published: May 31, 2021

Copyright $\odot 2021$ by author(s) and Scientific Research Publishing Inc. This work is licensed under the Creative Commons Attribution International License (CC BY 4.0).

http://creativecommons.org/licenses/by/4.0/

(c) (i) Open Access

\begin{abstract}
Solar irrigation pumps are considered as an alternative to the use of diesel and electric pumps due to the high cost of energy. These pumps are now increasingly used in the Niayes area. Thus, a more in-depth knowledge about the components of a solar pumping system and their characteristics available on the market as well as prices can be beneficial. This study was conducted to have an idea on the baseline of the use of solar irrigation pumps in this area. To perform this study, surveys were conducted among 12 suppliers and 10 service providers located in Dakar, Thies, Louga and Saint-Louis region and among 53 users located in Potou area which is in Louga region. Results show a wide range of pump brands and characteristics. Brands found were Lorentz, LIKOU, SHIMGE, Grundfos, Solar pump, Feili, Difful, JUQIANG, Solar tech, and Asaman. The pumps' flow rate varies between $2.5 \mathrm{~m}^{3} / \mathrm{h}$ and $45 \mathrm{~m}^{3} / \mathrm{h}$, the pressure ranges from $15 \mathrm{~m}$ to $160 \mathrm{~m}$ and the power is between $0.072 \mathrm{~kW}$ and $10 \mathrm{~kW}$. The price of these pumps varies depending on the brand used and their characteristics. In addition, other materials are available, such as panels with power ranging from $80 \mathrm{~W}$ to $330 \mathrm{~W}$ and electric cables. The price of these components varies according on the type used. Thus, the investment cost for implementation varies between 640 euros (420,000 CFA) and 25,087 euros $(16,455,919$ CFA). The cost of installation varies between 76.3 euros (50,000 CFA) and 1219.6 euros (800,000 CFA). Concerning maintenance, it is generally free during the warranty period when the equipment is supplied and installed by the same company. However, the cost of maintenance varies between 152.5 euros and 457.4 euros/year or is estimated at 45.7 euro/maintenance after the warranty years. Investigations conducted among users show that farmers
\end{abstract}


in general do not perform pump maintenance due to a lack of knowledge and financial means. Thus, according to farmers, factors that impact pumps operation are the low sunshine that occurs between December and January and the iron in the water and low well discharge.

\section{Keywords}

Solar Pumping System, Irrigation, Suppliers, Service Providers, Users, Niayes Area

\section{Introduction}

Water and energy consumption for irrigation is very important. Traditionally, electricity and fuel have been the main sources of energy used in pumping for irrigation in remote areas [1]. However, the inaccessibility of electricity and the high cost of diesel negatively impact on irrigation. Therefore, the use of solar energy in pumping water is considered a promising alternative to conventional energy [2]. Many developing countries are quickly adopting solar irrigation pumps [3].

During the last decade, a steady growth of solar energy has occurred in the world as an environmentally friendly and renewable energy resource. In fact, developed nations such as Germany, Spain, Italy, etc., and the United States of America are the main contributors to the success of solar energy. In recent years, solar photovoltaic industry development has outpaced all other renewable energy sources in the world. Nevertheless, solar photovoltaics in many developed counties is a recognized and realizable technology, while it is practically absent in African countries [4]. The use of solar irrigation pumps is considered a viable option for both large and small farmers due to lower investment costs and the increasing application of subsidy programs. Indeed, the use of solar pumps is possible in both large-scale and small-scale decentralized irrigation systems. Increasing demands for implementation, financing, and training from agricultural institutions in developing countries reflect the growing interest in solar-powered irrigation solutions worldwide [5]. Solar irrigation pumps are competitive with conventional power generation with significant recently photovoltaic cost reductions [6]. The cost of solar panels is continuously decreasing leading to their use in different sectors, namely the agricultural sector. For instance, the solar powered irrigation system is an appropriate alternative for farmers in given the present situation of energy crisis [7].

In the Niayes area in Senegal particularly, solar pumping is perceived as a very prospective solution enabling farmers to reduce their production costs. Currently, surface gasoline-powered pumps operating at a depth of up to 10 meters are practically used for groundwater pumping in irrigation besides hand pumps. In this regard, this area is considered one of the most potential areas for testing solar-powered pumping for intermediate irrigation depths for smallholders [8]. 
Also, solar irrigation pumps are becoming used by these farmers but without any prior study. For this purpose, it is important to assess the baseline of using solar irrigation pumps in the Niayes area in order to identify both the current status of the use of these pumps as well as the constraints to their implementation.

\section{Materiel and Method}

\subsection{Study Area}

The Niayes area is located in the north-west of Senegal, located between latitudes $14^{\circ} 55^{\prime}$ and $15^{\circ} 27^{\prime}$ and longitudes $16^{\circ} 50^{\prime}$ and $17^{\circ} 07^{\prime}$ west. It consists of a coastal narrow strip of $183 \mathrm{~km}$ long. It is part of the four regions: Dakar the capital of Senegal, Thies, Louga, and Saint-Louis (Figure 1) and bordering on the northern maritime fringe between Dakar and Saint-Louis [9].

\subsection{Data Collection and Method}

Surveys were conducted in order to collect data related to the equipment, characteristics and the cost of the different components, the cost of installation and maintenance and the constraint regarding the use of solar pumping systems

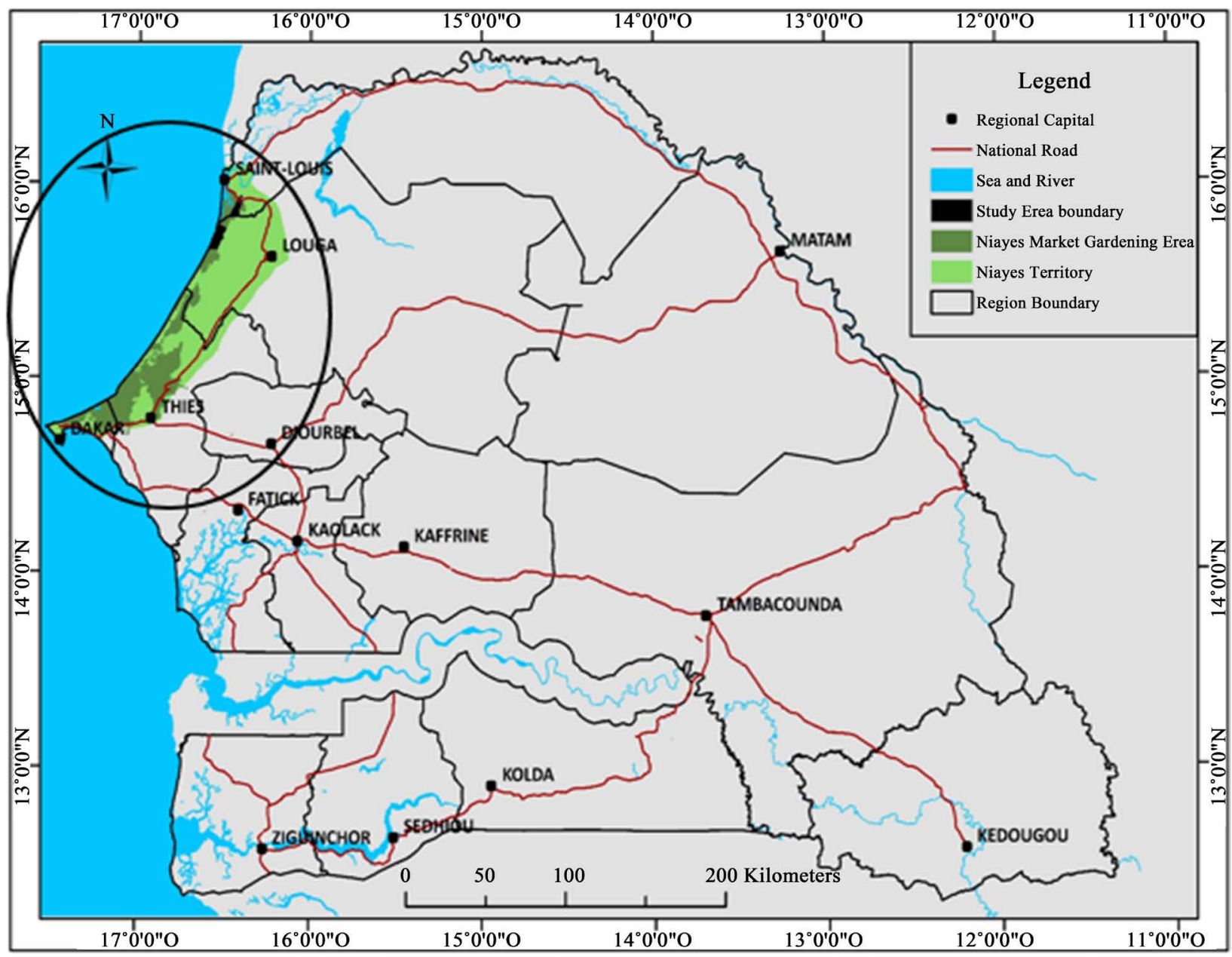

Figure 1. Localization of the Niayes study area. 
according to the farmers.

Surveys were conducted between December 2, 2019, and January 30, 2020 at three levels: 1) suppliers of solar irrigation pumps, 2) service providers that installed solar pumps in the Niayes area and 3) user located in Potou area in Louga region.

\subsubsection{Suppliers}

Surveys with suppliers were carried out with 12 suppliers in three region: Daker, Saint-Louis, Thies. Questionnaires were developed to get information about the components of a solar pumping system, the cost of each component, the brands of pumps existing on the market, the characteristics of these pumps (flow rate, pressure head, and power), etc. Realizing that suppliers of solar irrigation pumps are not very numerous. In total, 73 solar irrigation pumps were studied for 11 different brands.

\subsubsection{Service Providers}

Interviews were performed with 10 service providers in Saint-Louis, Dakar, Thies, Louga regions. These questionnaires were developed in order to find out the brands and characteristics (flow, pressure head, and power) of pumps that are installed in the Niayes area. 57 pumps models distributed over nine (9) brands were the subject of this study following the investigations.

\subsubsection{Users}

Potou area was selected to conduct the surveys with users. Potou is an area in which we find drip, sprinkler and manual irrigation systems. To carry out this study, a meeting was made with farmers using solar irrigation pumps in this area. It was conducted in order to identify the users of solar irrigation pumps, irrigation techniques used by each farmer and irrigation water distribution system at plot level (reservoir use or not). Following this meeting, sixty-five (65) farmers were identified in ten (10) separate villages in Potou area. The process followed to performed investigation with users is summarized in Figure 2.

Sampling was performed using Giezendanner's (2012) formula after identifying farmers having solar irrigation pumps in Potou area. Thus, the sample size was determined using the Equation (1).

$$
n=\frac{\left(t^{2} * N\right)}{\left(t^{\dot{e}}+\left(2 \epsilon^{2}\right) *(N-1)\right)}
$$

$n$ is the sample size, $N$ is the population size, $\epsilon$ is the margin of error, estimated at $5 \%$ with a confidence interval of $95 \%$, and $t$ is the confidence margin estimated at 1.69 and deducted from the Confidence interval.

After calculation, the sample size was estimated at 53 farmers. Knowing the sample size, it was necessary to determine the sampling rate, which was calculated using the Equation (2).

$$
R=\frac{n}{N}
$$




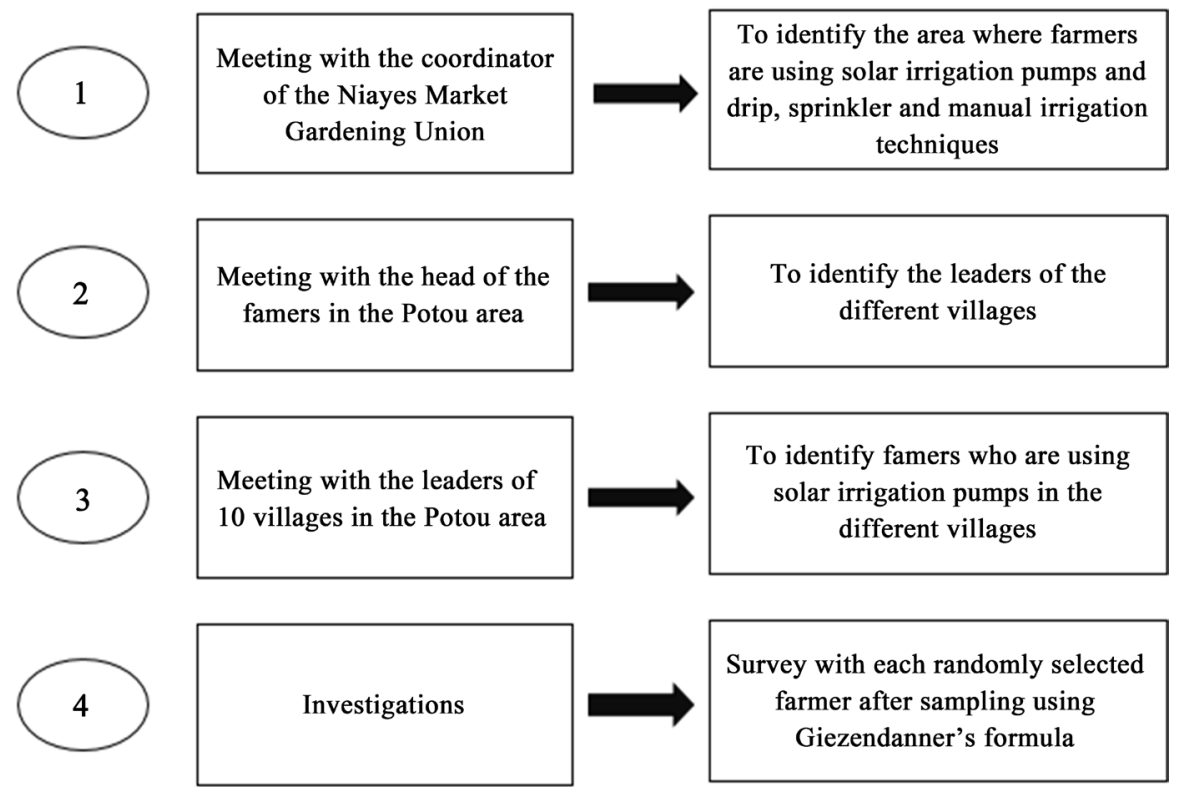

Figure 2. Process used to perform users' surveys in Potou area.

Table 1. Number of farmers using solar irrigation pumps in 10 villages and the sample size in Potou.

\begin{tabular}{ccc}
\hline Villages' names & Number of users of solar irrigation pumps & Sample size \\
\hline Ndialink & 9 & 7 \\
Maka & 7 & 6 \\
Sang (keur coura diery) & 5 & 4 \\
Gnayam & 4 & 3 \\
Keur Coura Gueyre & 4 & 3 \\
Gabar & 6 & 5 \\
Sagu Sathié & 5 & 4 \\
Wasou massal & 5 & 4 \\
Noreyni & 1 & 1 \\
Mouril & 19 & 15 \\
Total & 65 & 53 \\
\hline
\end{tabular}

$R$ is the sampling rate, $n$ is the sample size, and $N$ is the population size.

Table 1 gives the number of user of solar irrigation pumps in the Potou area and the number of farmer selected by using the sampling rate. Each farmer was selected randomly in the ten (10) villagers.

\section{Results and Discussion}

\subsection{Existing Solar Irrigation Pump Components on the Market}

\subsubsection{Pump Brands}

Different brands of pumps are available on the market: Lorentz, Solar pump, CNP, SHIMGE, LIKOU (Larens) and Grundfos, Feili, JUQIANG, Solar Tech, 
Difful, and Asaman (Figure 3).

Results show that Lorentz brand is the most present on the market. It represents $29.4 \%$ of the market pumps. While the Solar Pump and LIKOUbrand represent $11.8 \%$ of the market and CNP, SHIMGE, LIKOU (Larens), Grundfos, Feili, JUQIANG, Solar Tech, Difful, and Asaman brands are each accounting for $5.9 \%$ of the market. Lorentz, CNP, Grounfos, Feili, JUQIANG, Solar Tech, and Difful brands are mainly present in companies, and Solar Pump, SHIMGE, and LIKOU, and Asaman are available in shops. Suppliers are sourcing the pumps in different countries, such as Germany, China, India, Italy, Thailand, France, and Denmark. However, these pumps mainly originate from Germany (Lorentz), Denmark (Grundfoss) and China (all the other brands). The evaluation of the pumps on the basis of the country of manufacturing origin of the brand showed that $62.5 \%$ of the pumps are manufactured in China. These results are similar to those of [8] which showed that the majority of pumps on the market are of Chinese origin.

\subsubsection{Characteristics of Solar Irrigation Pumps Available on the Market} The pumps existing in the market have different characteristics. They vary from one pump to another and from one brand to another. These characteristics are flow rate, pressure head, and power.

\section{1) Pumps flow rate}

Figure 4 shows that pumps flow rate can be classified into four categories: a) less than $10 \mathrm{~m}^{3} / \mathrm{h}, \mathrm{b}$ ) from 10 to $20 \mathrm{~m}^{3} / \mathrm{h}, \mathrm{c}$ ) from 20 to $30 \mathrm{~m}^{3} / \mathrm{h}$ and d) from 30 to $45 \mathrm{~m}^{3} / \mathrm{h}$.

Pumps in the first class are the largest. They represent $63.2 \%$ of the pumps. Pumps with flow rate ranging from 10 to $20 \mathrm{~m}^{3} / \mathrm{h}$ represent $23.7 \%$ of the market and those that are between 20 to $30 \mathrm{~m}^{3} / \mathrm{h}$ represent $9.2 \%$ of the market. Only $3.9 \%$ of the pumps have flow rates ranging from 31 to $45 \mathrm{~m}^{3} /$ hour.

CNP, Solar Pump, JUQIANG, and Solar Tech brands are characterized by a

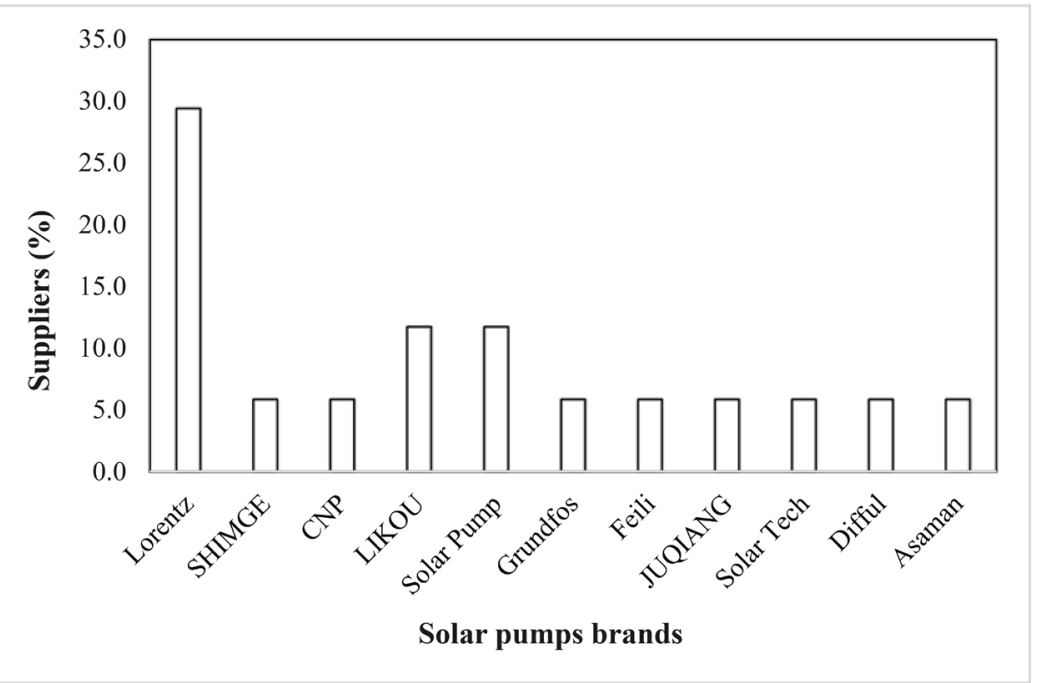

Figure 3. Existing solar irrigation pumps on the market. 


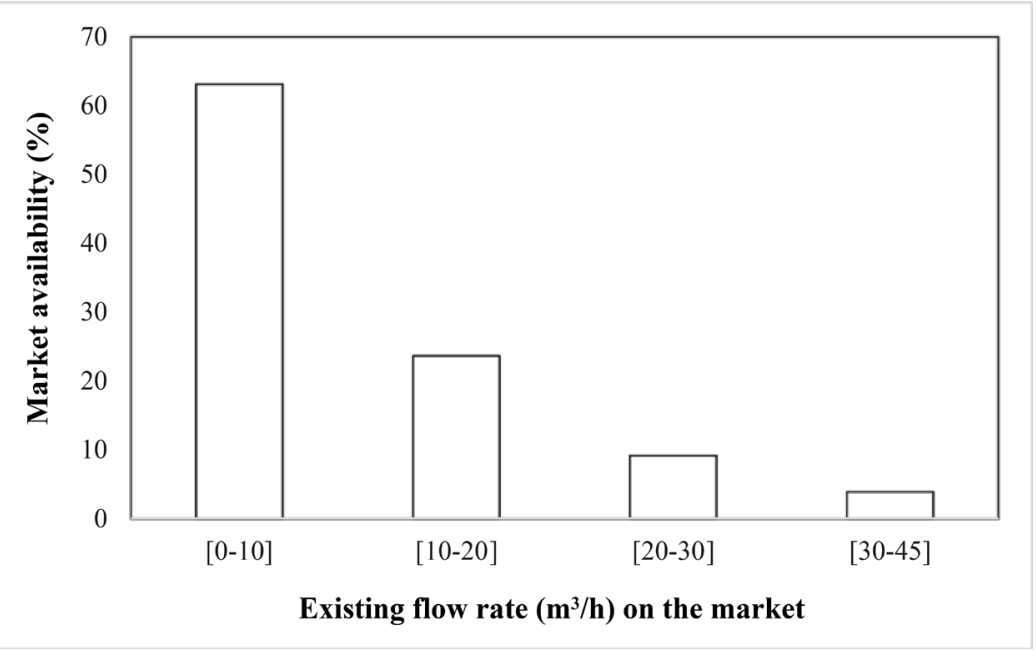

Figure 4. Existing flow rate on the market.

law variable flow rate. CNP brand exists with flow rates of 10 and $30 \mathrm{~m}^{3} / \mathrm{h}$, Solar pump brand has flow rates of $2.5,3$ and $6.5 \mathrm{~m}^{3} / \mathrm{h}$, JUQIANG brand has flow rate of $3 \mathrm{~m}^{3} / \mathrm{h}$ and $6.5 \mathrm{~m}^{3} / \mathrm{h}$, and Solar Tech exists with flow rate of $2 \mathrm{~m}^{3} / \mathrm{h}$. However, Lorentz, SHIMGE, LIKOU (Larens), Grundfos, Feili, Difful, and Asaman brands exist with more variable flow rates. Lorentz brand has flow rates ranging from 3 to $42 \mathrm{~m}^{3} / \mathrm{h}$ and the majority of this brand operates with flow rates varying between 6.5 and $14 \mathrm{~m}^{3} / \mathrm{h}$. LIKOU pumps have flow rates between 3.5 and $28 \mathrm{~m}^{3} / \mathrm{h}$ and most of them are between 6.5 and $25 \mathrm{~m}^{3} / \mathrm{h}$. About SHIMGE pumps, the flow rates are between 1.5 and $45 \mathrm{~m}^{3} / \mathrm{h}$ and the majority of these pumps have flow rates ranging from 3 to $10 \mathrm{~m}^{3} / \mathrm{h}$. Grundfos pumps have flow rate ranging from $0.63 \mathrm{~m}^{3} / \mathrm{h}$ to $19 \mathrm{~m}^{3} / \mathrm{h}$ with a majority operating between $0.65 \mathrm{~m}^{3} / \mathrm{h}$ and $12 \mathrm{~m}^{3} / \mathrm{h}$. Also, flow rates of Feili pumps range from $7 \mathrm{~m}^{3} / \mathrm{h}$ to $40 \mathrm{~m}^{3} / \mathrm{h}$, those of Difful pumps range from $5 \mathrm{~m}^{3} / \mathrm{h}$ to $15 \mathrm{~m}^{3} / \mathrm{h}$ and those of Asaman pumps range from 6 $\mathrm{m}^{3} / \mathrm{h}$ to $16 \mathrm{~m}^{3} / \mathrm{h}$. Overalls, the Lorentz and SHIMGE brands have pumps with higher flow rates. These pumps will satisfy farmers when water requirements are very high. In addition, the results in Figure 4 showed that the pumps available on the market for irrigation in the Niayes area are essentially low-flow pumps. This is due to the fact that farmers in the Niayes area mainly grow vegetable crops on relatively small areas of land, generally not exceeding 5 ha. Therefore, these pumps are able to satisfy the needs of farmers. In fact, solar irrigation pumps can have very high flow rates. These pumps can be used to irrigate rice, which is widely cultivated in Senegal. PSK2 pumps of the Lorentz brand are an example of this, with flow rates that can reach $767 \mathrm{~m}^{3} /$ hour, and as well as other pumps such as those of Feili and Difful brands that can have flow rates over 3000 $\mathrm{L} / \mathrm{h}$. Thus, the low flow rates of pumps available on the market are related to the fact that suppliers supply pumps in line with farmers' demands.

\section{2) Pumps pressure}

Figure 5 shows that pumps pressure is composed of four (4) categories: a) less than $50 \mathrm{~m}, \mathrm{~b}$ ) from $50 \mathrm{~m}$ to $100 \mathrm{~m}, \mathrm{c}$ ) from 100 to $150 \mathrm{~m}$ and d) from $150 \mathrm{~m}$ to 


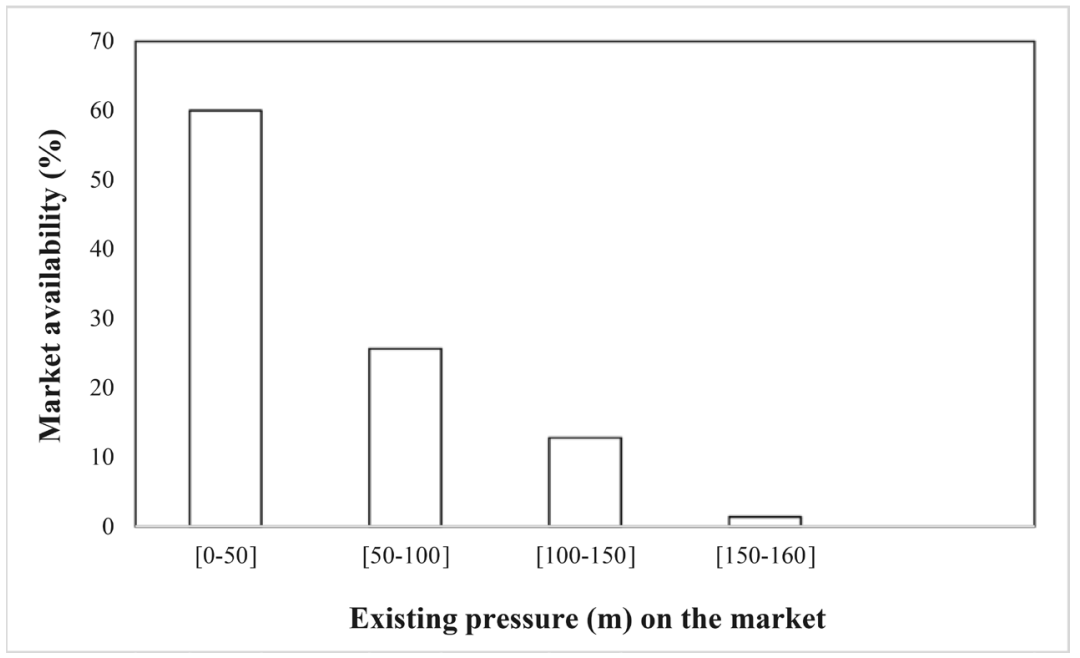

Figure 5. Existing pressure head on the market.

$160 \mathrm{~m}$.

Figure 5 shows that the existing solar pumps on the market have pressures ranging from $15 \mathrm{~m}$ to $160 \mathrm{~m} .57 .5 \%$ of these pumps have pressures that range between $15 \mathrm{~m}$ and $50 \mathrm{~m}$ and $24.7 \%$ are between $51 \mathrm{~m}$ and $100 \mathrm{~m}$. Only $16.4 \%$ have pressures greater than $100 \mathrm{~m}$. Pumps with pressures between 100 and 150 $\mathrm{m}$ represent $12.3 \%$ of the market, those with pressure of more than 160 account for $2.7 \mathrm{~m}$. In addition, pump pressure is also highly variable from one brand to another.

Results show that Grundfos and Lorentz are larger in pressure. Pressure for Grundfos ranges between 15 and $120 \mathrm{~m}$. Lorentz pumps have pressures from 15 to $160 \mathrm{~m}$ and the majority are between 30 and $70 \mathrm{~m}$. Pressure of LIKOU (Larens) pumps varies between 30 and $140 \mathrm{~m}$ and most of the pumps have pressures between $40 \mathrm{~m}$ and $85 \mathrm{~m}$. Concerning SHIMGE pumps, it is between 36 and $90 \mathrm{~m}$ and most of them have pressures ranging from $40 \mathrm{~m}$ to $50 \mathrm{~m}$. For Solar pumps, the pressure varies from 30 to $95 \mathrm{~m}$ and the largest part of these pumps have pressures less than or equal to $60 \mathrm{~m}$. Feili brand pumps have pressures ranging from $40 \mathrm{~m}$ to $130 \mathrm{~m}$. JUQIANG pumps pressures are between $20 \mathrm{~m}$ and $95 \mathrm{~m}$ and most of them have pressures not exceeding $50 \mathrm{~m}$. Also, the pressure of Asaman pumps varies between $50 \mathrm{~m}$ and $110 \mathrm{~m}$. On the other hand, CNP, Difful and Solar Tech brands have pressures with a slight variation. The pressure of CNP pumps is either equal to $25 \mathrm{~m}, 39 \mathrm{~m}$ or $59 \mathrm{~m}$. Difful pumps have pressures that are alternatively either $40 \mathrm{~m}$ or $50 \mathrm{~m}$, while CNP pumps have pressures that are either $25 \mathrm{~m}, 39 \mathrm{~m}$ or $59 \mathrm{~m}$. Solar Tech brand pumps have a pressure of 132 $\mathrm{m}$. The majority of pumps available for all brands except Grundfos have pressures below $100 \mathrm{~m}$. This is because in the north of Niayes area, more precisely in the Saint-Louis area, the groundwater table is between $6 \mathrm{~m}$ and $12 \mathrm{~m}$. This means that the depth of the wells varies between 12 and $25 \mathrm{~m}$. The deepest wells in which the pumps are installed are generally located in Thies with depths of up to $35 \mathrm{~m}$. Therefore, these pumps are able to meet the needs of the farmers. 


\section{3) Pumps power}

Figure 6 shows that the pump power is divided into six (6) categories: a) less than $1 \mathrm{~kW}, \mathrm{~b}$ ) from 1 to $2 \mathrm{~kW}, \mathrm{c}$ ) from 2 to $3 \mathrm{~kW}, \mathrm{~d}$ ) from 3 to $4 \mathrm{~kW}$, e) from 4 to $5 \mathrm{~kW}$ and more than $5 \mathrm{~kW}$.

Figure 6 shows that solar irrigation pumps available from suppliers on the market range from $0.072 \mathrm{KW}$ to $10 \mathrm{KW}$. However, $72.4 \%$ of these pumps have powers less than or equal to $2 \mathrm{KW}$. $38.2 \%$ of the pumps have powers from 0.072 $\mathrm{kW}$ to $1 \mathrm{~kW}$ and $34.1 \%$ are between $1 \mathrm{~kW}$ and $2 \mathrm{~kW}$. Pumps with powers above $4 \mathrm{~kW}$ are not very important on the market and represent about $7.9 \%$ of the existing pumps. Also, pump power is highly variable from one brand to another.

In addition, Lorentz pump brands have higher power ratings compared to other pump brands. Power of Lorentz pumps ranges from 0.15 to $10 \mathrm{~kW}$. But most of these pumps have flow rates that vary between 0.6 and $4 \mathrm{~kW}$. This is followed by the Feili brand pumps which have powers ranging from $0.75 \mathrm{~kW}$ to $7.5 \mathrm{~kW}$. SHIMGE pumps range from 72 to $5000 \mathrm{~W}$ with the majority having power ratings from 0.4 to $1.3 \mathrm{~kW}$. The power of LIKOU (Larens) pumps fluctuate between 0.4 and $4 \mathrm{~kW}$ with the majority having power less than or equal to $2.2 \mathrm{~kW}$. The Solar pump and JUQIANG brands have lower powers. Solar pump has powers of between 0.2 and $1.5 \mathrm{KW}$ and JUQIANG has powers ranging from $0.2 \mathrm{~kW}$ to $1.5 \mathrm{~kW}$. These brands are mainly composed of pumps with flow rates less than or equal to $0.75 \mathrm{~kW}$. In addition, the power of the CNP, Grundfos Difful, Solar Tech, and Asaman brands are not so variable. CNP pumps power is either $1.5 \mathrm{~kW}, 2.2 \mathrm{~kW}$ or $3 \mathrm{~kW}$. For Difful pumps, the power is equal to either $0.75 \mathrm{~kW}$ or $1 \mathrm{~kW}$. Asaman pumps are available in $1.5 \mathrm{~kW}$ or $2.2 \mathrm{~kW}$.

Solar Tech and Grundfos pumps have capacities of $0.6 \mathrm{~kW}$ and $1.4 \mathrm{~kW}$ respectively. Pumps available on the market have more or less low power ratings. That is explained by the fact that these pumps have more or less low flow rates and pressures ( $86.8 \%$ have flow rates less than or equal to $15 \mathrm{~m}^{3} / \mathrm{h}$ and $82.2 \%$ have pressures less than or equal to $95 \mathrm{~m}$ ). As a result, the power of these pumps

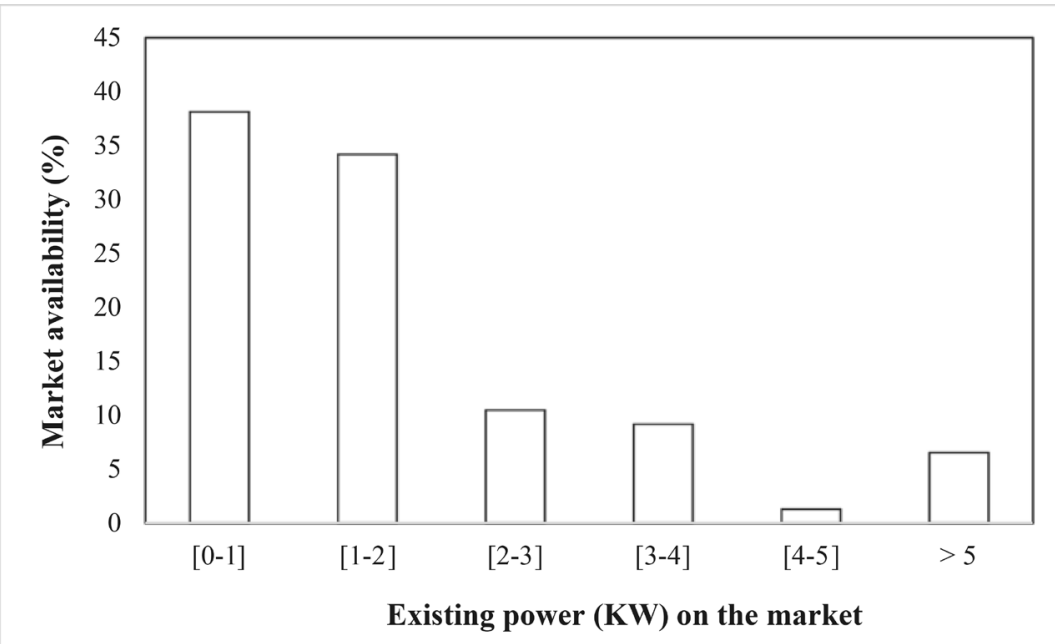

Figure 6. Existing power on the market. 
is sufficient for water pumping.

\subsubsection{Relationship between Flow, Pressure and Power}

Results show that pressure head and power of the available pumps decreases as the flow rate increases. Pumps with flow rates between $0.63 \mathrm{~m}^{3} / \mathrm{h}$ and $10 \mathrm{~m}^{3} / \mathrm{h}$ are more variable in term of pressure head. The pressure of these pumps varies between $20 \mathrm{~m}$ and $160 \mathrm{~m}$ and the power ranges from $0.15 \mathrm{~kW}$ and $2.2 \mathrm{~kW}$. Pumps with flow rates between $12 \mathrm{~m}^{3} / \mathrm{h}$ and $19 \mathrm{~m}^{3} / \mathrm{h}$ have pressures between 15 $\mathrm{m}$ and $160 \mathrm{~m}$ and those with flow rates ranging from $22 \mathrm{~m}^{3} / \mathrm{h}$ to $30 \mathrm{~m}^{3} / \mathrm{h}$ have pressures which range from $50 \mathrm{~m}$ to $190 \mathrm{~m}$. The lowest pressures are obtained with pumps that have flow rates greater than $30 \mathrm{~m}^{3} / \mathrm{h}$. The pressure of these pumps turns around $49 \mathrm{~m}^{3} / \mathrm{h}$. In addition, these results confirm the results of Figure 2 which shows that the majority of available solar irrigation pumps have more or less low flow rates ranging from $0.63 \mathrm{~m}^{3} / \mathrm{h}$ to $30 \mathrm{~m}^{3} / \mathrm{h}$ in line with the demand of farmers in the Niayes area.

According to the suppliers, the most commonly used pumps in the Niayes area are those with flow rates ranging from $3 \mathrm{~m}^{3} / \mathrm{h}$ to $28 \mathrm{~m}^{3} / \mathrm{h}$ and pressures from 15 $\mathrm{m}$ to $140 \mathrm{~m}$. Most of these pumps have flow rates of less than $15 \mathrm{~m}^{3} / \mathrm{h}$ and pressures of less than $50 \mathrm{~m}$. According to suppliers, these choices are explained by the fact that farmers in the Niayes have surfaces of less than 5 hectares in size, which is in line with the results of [10], pointing out that about $90 \%$ of farmers in Senegal have plots of less than 5 hectares. Also the depths of the water table vary between $6 \mathrm{~m}$ and $12 \mathrm{~m}$ and drillings depths do not exceed $25 \mathrm{~m}$. As a result, these pumps enable farmers to meet their irrigation water needs. These pumps are available at affordable prices making them accessible to all farmers.

\subsubsection{Price of the Solar Irrigation Pumps Available on the Market}

Pump prices per power unit for the different pump brands, based on flow rates are shown in Figure 7.

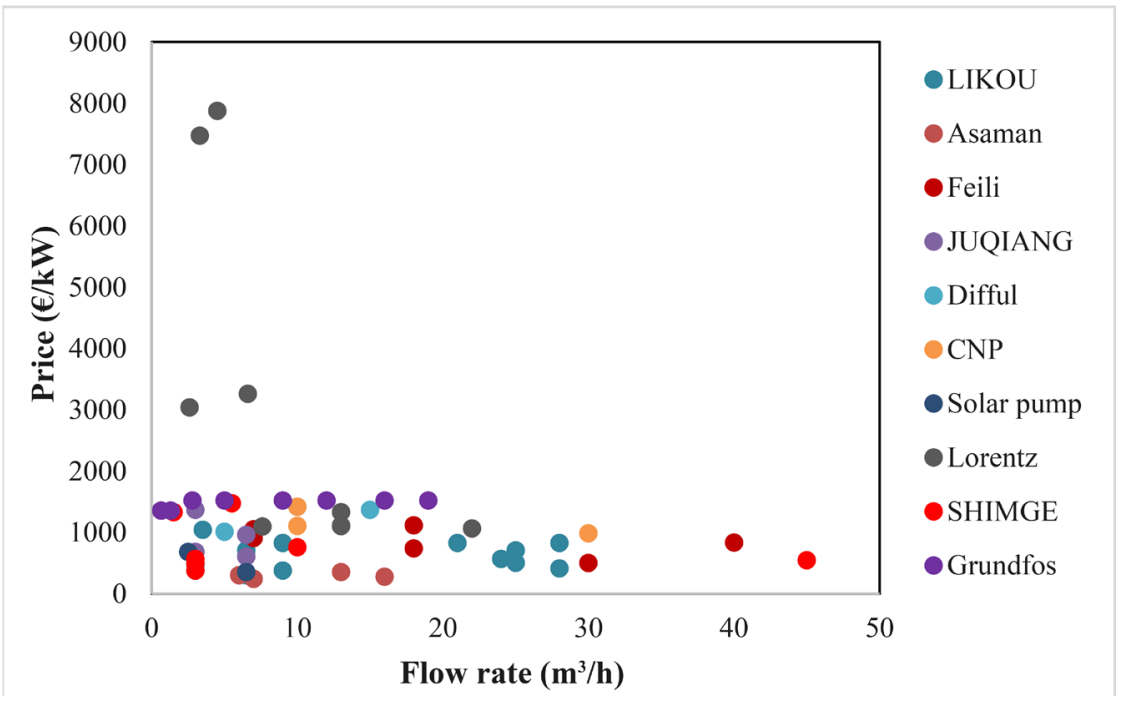

Figure 7. Prices variation by brand. 
The price varies depending on the brand. Lorentz brand pumps have a higher cost which varies between $1064 € / \mathrm{kW}$ and $7879 € / \mathrm{kW}$ for a flow rate that varies between $2.6 \mathrm{~m}^{3} / \mathrm{h}$ and $22 \mathrm{~m}^{3} / \mathrm{h}$. SHIMGE, LIKOU, Solar pump, and Asaman pumps are cheaper. The price of these pumps varies between 242 and 1478 $€ / \mathrm{kW}$. In addition, Grundfos brand pumps are very expensive (1357 to 1520 $€ / \mathrm{kW}$ ) despite their low flow rate. Indeed, the price of the pumps is higher for Lorentz pumps compared to the other brands. This is due to the fact that Lorentz pumps have higher flow rates and power ratings. In addition, according to the suppliers, the service life of Lorentz brand pumps is higher, up to 10 years or more. In addition, prices are lower for some SHIMGE, Solar Pump and JUQIANG pumps. This is because these pumps have low flow rates, pressures as well as powers and are not equipped with controllers. Also, the high cost of Grundfos brand is due to their high-pressure head.

In addition, a comparative study between the prices of the pumps available from suppliers with whom these surveys were conducted and the prices of these pumps in the e-commerce sites showed that the prices of the pumps are higher with our suppliers. For example, Lorentz solar irrigation pumps ranged from 1185.31 Euros (777,512 CFA, local money) to 6095.88 Euros (16,455,919 CFA) at suppliers. However, for the same pumps, the price varied between 1017.45 Euros (670,404 CFA) and 3144.5 Euros (2,071,928 CFA) on e-commerce sites. The difference is much more significant in the case of Difful brand and LIKOU (Larens) brands. Indeed, a LIKOU brand pump with a flow rate of $3.5 \mathrm{~m}^{3} / \mathrm{h}$, a pressure of $40 \mathrm{~m}$ and a power of $400 \mathrm{~W}$ costs 419.24 euros (275,000 CFA) at the suppliers' whereas it costs 185.23 euros (121,500 CFA) on average in the e-commerce sites. For Difful brand, a pump with $5 \mathrm{~m}^{3} / \mathrm{h}$ flow, $50 \mathrm{~m}$ pressure, and $750 \mathrm{~W}$ power costs 762.25 euros (500,000 CFA) at the suppliers', while it costs 265.38 euros (174,960 CFA). These significant differences are related to the high cost of customs clearance, taxes, etc. Thus, the Senegalese government can reduce the costs associated with these expenses to allow suppliers to reduce the prices of these pumps to facilitate access to farmers.

\subsubsection{Other Components}

In addition to the pumps, all the equipment of the solar pumping system is available on the market. These components are the panels, controllers and electrical wiring. $88.9 \%$ of suppliers have all solar pumping system equipment available. Most of the suppliers do not have any difficulty in getting the equipment's on time. However, $33.3 \%$ have difficulties related to customs clearance.

\section{1) Panels}

The solar panels that exist on the market are either made of monocrystalline sillicum or polycrystalline sillicum. These modules exist under a wide range of power (Table 2).

Panels with a power of $250 \mathrm{~W}$ represent $62.5 \%$ of the market. According to the suppliers they are not expensive and allow users' needs to be satisfied. The panels with a power lower than $200 \mathrm{~W}$ present on the market are exclusively made 
of monocrystalline silicon, while those with powers higher than $200 \mathrm{~W}$ exist with either monocrystalline or polycrystalline silicon. According to the companies, panels made of monocrystalline silicon are more expensive than panels made of polycrystalline silicon. This price difference is linked to higher energy production in monocrystalline silicon panels. Thus, $80 \%$ of the enterprises commercialize panels made of polycrystalline silicon with powers varying between 250 and $330 \mathrm{~W}$. The prices of the panels vary greatly from one company to another. Nevertheless, they vary between $130 €(85,000 \mathrm{CFA})$ and $191 €(125,000 \mathrm{CFA})$.

However, shops do not have a good perception of the difference between monocrystalline and polycrystalline silicon panels. As a result, a monocrystalline silicon panel and a polycrystalline silicon panel with the same power are sold at the same price. In addition, the solar panels available in shops or companies come mainly from China. Prices are fixed for panels of the same power in the different shops (Figure 8).

Figure 8 shows that variation in price is highly correlated with variation in panel power. The determination coefficient of $0.98 \%$ shows that the variability explained by the regression is very close to the total variability of the data. Thus, results show a very good correlation between the price and the power of modules as explained by the determination coefficient of 0.98 , which is significant. Price of panels increases with the increase of power. Solar panels available in the shops have power ratings from $80 \mathrm{~W}$ to $300 \mathrm{~W}$ with prices ranging from 53 Euros (35 000 CFA) to 152 Euro (100,000 CFA). An increase in price of $40 €$ occurs with an increase of $100 \mathrm{~W}$ of the modules power in shops. In addition, these results show that the cost of solar panels is lower in shops compared to companies.

Table 2. Availability of solar panels on the market.

\begin{tabular}{|c|c|c|c|c|c|c|c|c|c|c|c|c|c|}
\hline Power (W) & 80 & 100 & 120 & 150 & 200 & 240 & 250 & 270 & 275 & 280 & 300 & 310 & 330 \\
\hline Availability on the market (\%) & 12.5 & 12.5 & 12.5 & 12.5 & 12.5 & 12.5 & 62.5 & 25 & 12.5 & 12.5 & 25 & 12.5 & 12.5 \\
\hline
\end{tabular}

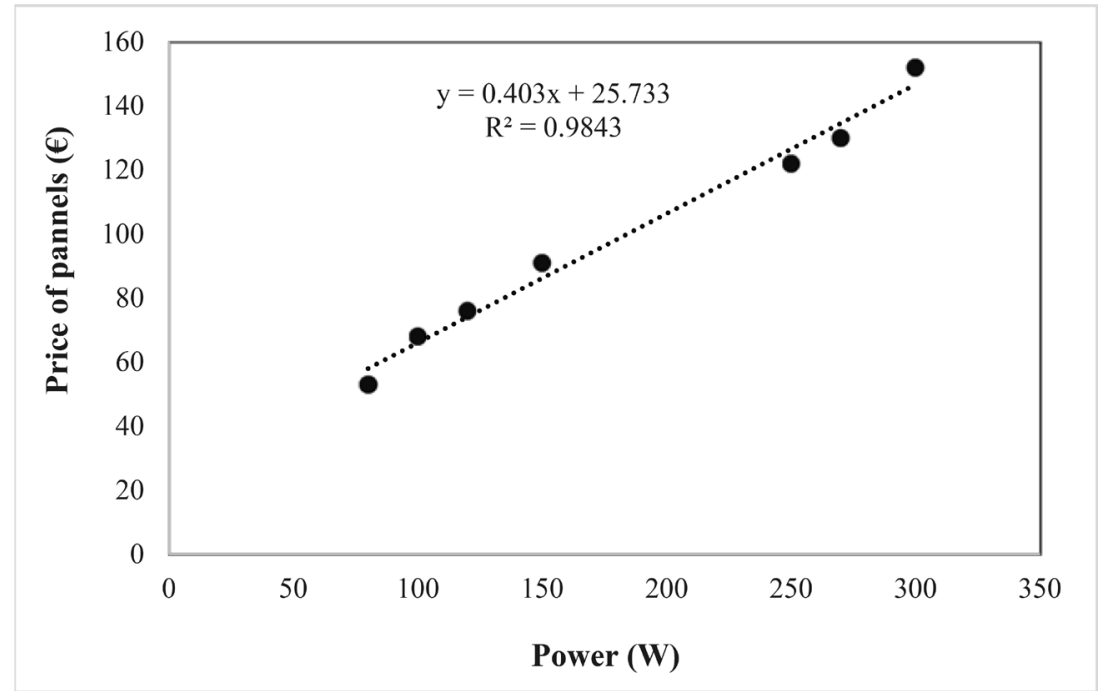

Figure 8. Price of panels on shop. 


\section{2) Controller and electrical wiring}

According to the suppliers, all solar irrigation pumps are equipped with a controller except for some SHIMGE and Solar pump brand pumps. Also, they are equipped with electrical wiring. However, these controllers may fail so that it becomes impossible to use them. Thus, there are controllers on the market. There are $1.5 \mathrm{~kW}$ and $2.2 \mathrm{~kW}$ controllers with currents of 96 and $280 \mathrm{~V}$ respectively. They cost 183 euros (120,000 CFA) and 274 euros (180,000 CFA) respectively. In addition, electric cables are available on the market. These cables are used in cases where the size of the cables is insufficient to carry out the installation. The cables that connect the pump to the panels cost between EUR 3.1 (2000 CFA) and 5.4 (3500 CFA) per meter, while the cables that connect the panels cost between EUR 1.5 (1000 CFA) and 2.3 (1500 CFA) per meter.

\subsection{Pump Warranty Period and After-Sales Service}

\subsubsection{Pump Warranty Period}

The warranty period of the pumps differs according to the brand and the capacity of the pumps. Some pumps are not guaranteed by the suppliers on the market. These are SHIMGE brand pumps with flow rates under or equal to $3 \mathrm{~m}^{3} / \mathrm{h}$ and Solar pump brand pumps with flow rates up to $6.5 \mathrm{~m}^{3} / \mathrm{h}$. SHIMGE brand pumps with a flow rate greater than $3 \mathrm{~m}^{3} / \mathrm{h}$ are guaranteed over a period of 1 year and Solar pump brand pumps are warranted over a period of 6 months. LIKOU (Larens) pumps have a 3 to 4 years warranty. Feili brand pumps are guaranteed for 2 years and JUQIANG brand pumps are not guaranteed because they are small pumps, without a controller and their prices do not offer any warranty. Lorentz pumps are covered by a warranty of 2 to 3 years and Grundfos pumps have a 2-year warranty. However, these pumps have a lifetime of 5 to 10 years.

\subsubsection{After-Sales Service}

The maintenance of the solar pumping system is not carried out by all suppliers. In fact, only $67 \%$ of the suppliers carry out maintenance after the sale (Figure 9).

The after-sales service is mainly carried out by the companies that sell and install the solar pumping system. It is free of charge during the warranty years. However, after these years, the farmers will be required to pay for the maintenance. Moreover, shops only provide equipment for sale and do not take care of after-sales maintenance. However, they are often working with designers who can perform maintenance of the pumping system after installation.

\subsection{Solar Pumping Components Installed by Service Providers}

\subsubsection{Pumps Installed by Service Providers}

In the Niayes area, solar irrigation pumps are installed by companies that sell and install pumps or by private individuals working independently for themselves. In fact, $87 \%$ of the service providers are companies having their own engineers to ensure the design and installation of pumps after sale of the equip- 
ment. Only $13 \%$ of service providers are private entrepreneurs working individually. According to the service providers, the pumps installed in the Niayes area are essentially submersible pumps because the only source of water available for irrigation in the Niayes area is groundwater. Several brands of pumps are installed by the service providers. Most of service providers install only one brand of pump. This is most commonly observed in companies that often sell only one pump brand. The most installed solar irrigation pump brands in this area are Lorentz, CNP, Grundfos, Solar Tech, Difful, Feili, Asaman, Solar Pump, LIKOU (Larens) and JUQIANG (Figure 10).

Figure 10 shows that Lorentz is the most installed brand by service providers. Indeed, Lorentz brands account for $40 \%$ of the brands installed. CNP, Grundfos, Solar Tech, Difful, Feili, JUQIANG, Asaman, Solar Pump, and LIKOU (Larens) pump brands each represent $7 \%$ of pumps installed by service providers. These results are similar to the results from the suppliers' surveys. In fact, the pumps

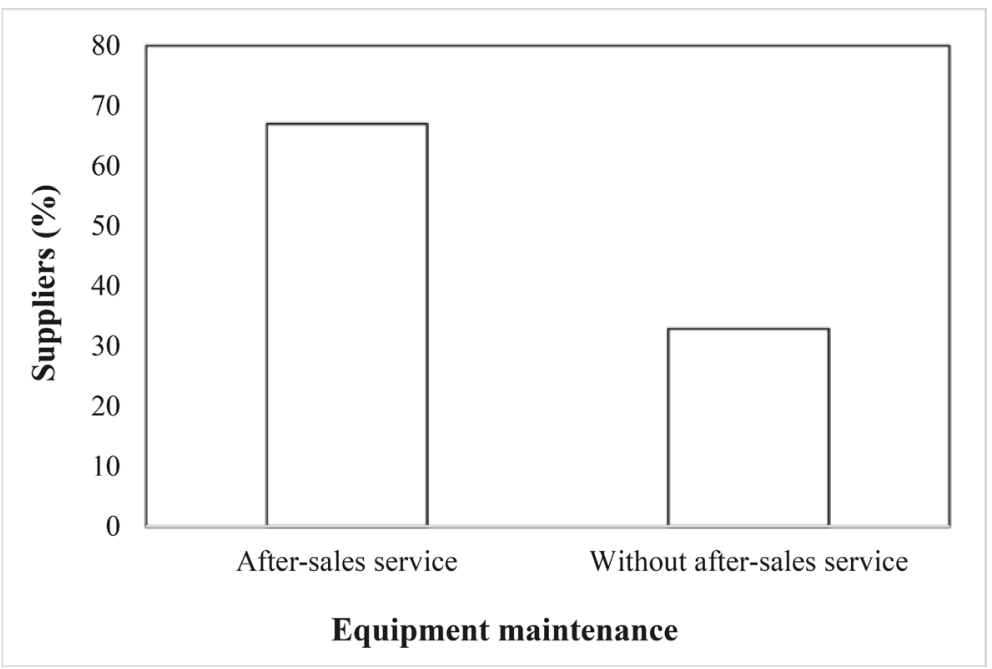

Figure 9. After sales service.

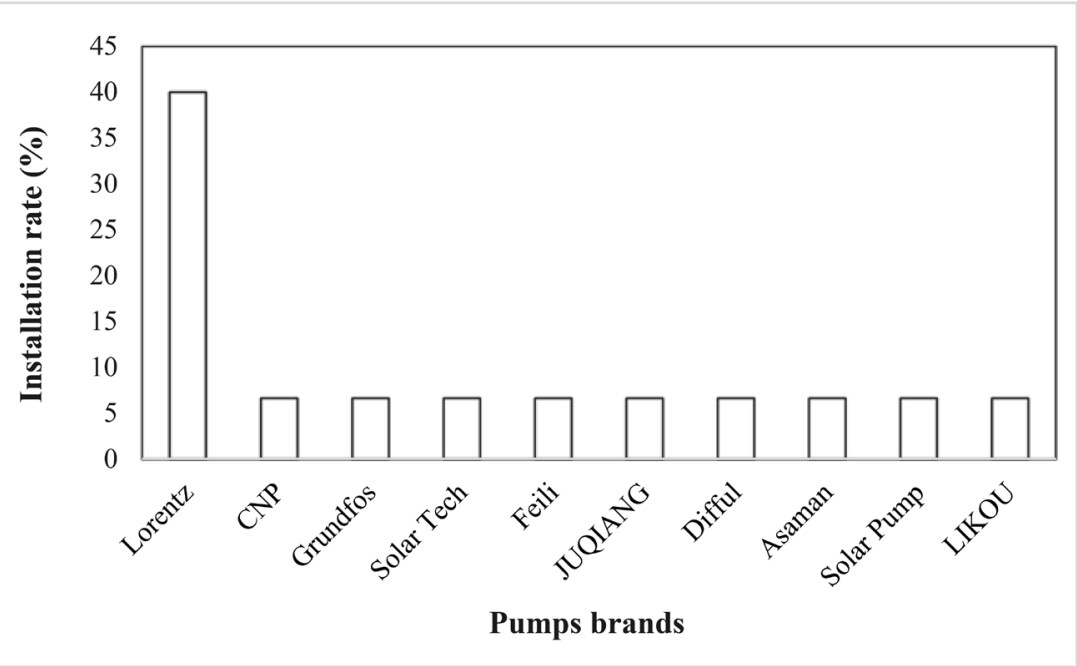

Figure 10. Most common solar pumps brands. 
installed by the service providers are the same pumps available from the suppliers. According to the service providers, the larger installation of the Lorentz brand results from the fact that $58 \%$ of the service providers are companies that sell and install solar irrigation pumps. Among these companies, $86 \%$ of companies are exclusively selling Lorentz brand pumps or are selling Lorentz brand pumps in combination with other pumps altogether. According to these companies, Lorentz brand pumps are more expensive, however, they have a longer lifetime and offer better quality. They are equipped with sensors (Sun switch) that automatically stop pump operation when there is insufficient water in the wells. They are also equipped with regulators attached to the panels allowing regulation of the power required to operate the pump during periods of low sunshine. However, according to service providers, CNP, Grundfos, Solar Tech, Difful, Feili, JUQIANG, Asaman, Solar Pump, and LIKOU (Larens) pumps are widely used by farmers because they are very efficient in Niayes and the costs are affordable.

Pumps installed by service providers have flow rates from $0.63 \mathrm{~m}^{3} / \mathrm{h}$ to 40 $\mathrm{m}^{3} / \mathrm{h}$, pressures ranging from $15 \mathrm{~m}$ to $200 \mathrm{~m}$ and powers varying from $0.2 \mathrm{~kW}$ to $5.5 \mathrm{~kW}$. According to the service providers, the most commonly used pumps in the Niayes area have flow rates ranging from $3 \mathrm{~m}^{3} / \mathrm{h}$ to $30 \mathrm{~m}^{3} / \mathrm{h}$, pressures varying between $15 \mathrm{~m}$ and $95 \mathrm{~m}$ and powers from $0.4 \mathrm{~kW}$ to $3 \mathrm{~kW}$, with the exception of pumps of the Grundfos and Solar Tech brands. These pumps have lower flow rates with higher pressures. This is because farmers in the Niayes area are private producers with small plots of land and low resources. In addition, the water table is usually between $6 \mathrm{~m}$ and $12 \mathrm{~m}$, so the wells on which the pumps are installed vary between $12 \mathrm{~m}$ and $35 \mathrm{~m}$. Therefore, these pumps allow them to meet their irrigation water needs.

Solar panels power installed by the suppliers vary between $250 \mathrm{~W}$ and $300 \mathrm{~W}$. However, modules with power ratings above $270 \mathrm{~W}$ are very rarely installed. In fact, $87.5 \%$ of the panels installed have powers of $250 \mathrm{~W}$. This result is slightly similar to the results generated from the suppliers' survey which showed that $62 \%$ of the panels available on the market have powers of $250 \mathrm{~W}$. Some service providers have justified this on the basis that panels made of polycrystalline silicon are cheaper and are more available on the market, which correlates with the results of supplier surveys. However, for the others, this is related to the fact that polycrystalline silicon-based modules are more suitable for areas with high levels of sunlight such as Senegal. This hypothesis is supported by Damme \& Sautrot (2006) [11]. According them, polycrystalline panels are not very sensitive to variations in illumination, which is not the case with monocrystalline silicon panels. Thus, panels made from polycrystalline silicon are more recommended for areas with high levels of sunlight because they are designed to be unheated.

\subsubsection{Installation Cost and Maintenance}

\section{1) Installation cost}

The cost of pump installation in the Niayes area is quite variable for the dif- 
ferent pumps (Table 3).

The installation cost of the most commonly implemented solar irrigation pumps in the Niayes area varies between 76.23 euros and 1219.59 euros. According to the service providers, the cost of installing a solar pumping system depends on the environmental conditions in which the pump will be installed, the size of the pump, the number of panels that will be installed, and the accessibility of the area. The highest installation cost is obtained from Lorentz brand. Indeed, the installation cost of these pumps varies between 381.12 euros and 1219.59 euros. The cost of Solar Tech and Difful varies between 152.45 euros and 533.57 euros. Regarding Feili and JUQIANG brands, the cost varies between 76.23 euros and 686.02 euros. For Solar Pump and Asaman pumps, the installation cost varies between $152.45 €$ and $318.12 €$. In addition, the cost of the installation of the CNP and Grundfos brands varies slightly. For the CNP brand, it ranges from 419.24 euros to 457.35 euros. For the Grundfos brand, it is around $533.57 €$.

\section{2) Solar pumping system maintenance}

After installation of solar pumping systems can be carried out by all service providers. $87 \%$ of the service providers employed in companies that sell and install the pumps provide free maintenance during the warranty period. However, farmers are obliged to pay for maintenance after the warranty years. For the majority of service providers, the cost of maintenance is low and varies depending on the water quality and the pump's condition. Some service providers estimate the annual maintenance cost of the pumping system between $€ 152.45$ and $€ 457.35$. For others, the cost of maintenance is around $45.74 €$ at each maintenance visit. Maintenance consists of:

- flooding the pump;

- disassemble and repair the pump in case of failure;

- inspection of the connection network;

- checking the voltage and the solar panels.

According to the service providers, maintenance is performed at the end of each crop season if water quality is suitable. However, it is carried out every 4 to 2 months when the well water is charged.

\subsection{Evaluation of the Investment Cost for Solar Pumping System Installation by Suppliers}

The investment cost of a solar irrigation pumping system can be determined based on prices provided by companies. Indeed, $50 \%$ of the suppliers of solar

Table 3. Installation cost of solar irrigation pumps in the Niaye region.

\begin{tabular}{cccccc}
\hline Pumps brands & Lorentz & CNP & $\begin{array}{c}\text { Solar Tech } \\
\text { and Difful }\end{array}$ & $\begin{array}{c}\text { Feili and } \\
\text { JUQIANG }\end{array}$ & $\begin{array}{c}\text { Solar Pump } \\
\text { and Asaman }\end{array}$ \\
\hline Minimum prices $(€)$ & 381.12 & 419.24 & 152.45 & 76.23 & 152.45 \\
Maximum prices $(€)$ & 1219.59 & 457.35 & 533.57 & 686.02 & 381.12 \\
\hline
\end{tabular}


irrigation pumps are companies that have their own service providers that take care of the installation. Thus, the price of all the material and the installation are grouped in one price. Therefore, it represents the cost of the investment. Pumps that are sold and installed by the companies are Lorentz, Feili, CNP, Difful, JUQIANG, and Solar Tech branded pumps.

Considering Lorentz brand, which is installed by $80 \%$ of the companies and which costs more, it has been found that the investment cost of solar irrigation pumps varies between 2286.74 euros (1,500,000 CFA) and 25,086.89 euros $(16,455,919$ CFA). Among these pumps, the most installed in the Niayes area are the PS600, PS1800, and PS4000. PS600 pumps have flow rates of up to $12 \mathrm{~m}^{3} / \mathrm{h}$ and are generally used in areas of 0.5 to 1 ha. PS1800 pumps have flow rates of up to $15 \mathrm{~m}^{3} / \mathrm{h}$ and are used on areas of 1 to 2 ha. PS4000 pumps have flow rates of up to $24 \mathrm{~m}^{3} / \mathrm{h}$ and are generally used on surfaces of more than $2 \mathrm{ha}$. The price of the PS600 is fixed for all companies. It is estimated at 3811.24 euros. However, the investment cost of the PS1800 and PS4000 varies from one company to another. The investment cost of the PS1800 pumps varies between 5457.67 euros and 5640.61 euros. Investment costs for PS1800 pumps are very close in the different companies. However, the difference in costs is significant for PS4000 pumps. The investment cost of PS4000 pumps ranges from 6402.86 euros to $11,078.47$ euros. The variation in price is mainly due to the difference in the number and power of panels, the diameter of the piping, as well as the type of cabling used during installation. In addition, the change in investment cost is related to the expensive cost of customs clearance for some of them, which has an impact on prices. In addition, the investment cost to implement Feili pumps varies between 1920.86 Euros (1,260,000 CFA) and 8384.70 Euros $(5,500,000)$. That of JUQIANG brand ranges from 640.29 Euros (420,000 CFA) to 3018.49 Euros (1,980,000 CFA). For CNP brand pumps, the cost of installation is either equal to 4344.80 Euros $(2,850,000 \mathrm{CFA})$ or 5267.11 Euros $(3,455,000 \mathrm{CFA})$ or equal to 6494.33 Euros $(4,260,000)$. Difful pumps cost 1631.20 Euros $(1,070,000$ CFA), 2667.86 Euros (1,750,000 CFA) or 3430.10 Euros (2,250,000 CFA). The investment cost for the installation of solar irrigation pumps is cheaper for Difful and JUQIANG brand pumps. This is due to the fact that Difful pumps are generally low power pumps $(0.75 \mathrm{~kW}$ to $1 \mathrm{~kW})$ that are installed with 4 to 6 panels. Also, JUQIANG pumps are small pumps with low flow rates of $3 \mathrm{~m}^{3} / \mathrm{h}$ to $6.5 \mathrm{~m}^{3} / \mathrm{h}$.

\subsection{Use of Solar Pump by Farmers in Potou Area}

\subsubsection{Pumps Characteristics}

Surveys have shown that farmers do not know the brands of pumps they are using. Only those with Lorentz pumps have knowledge of the brands of pumps they have. In fact, according to farmers, the Lorentz brand pumps are of better quality and therefore these pumps are known by all farmers. However, it also emerges from these surveys that farmers do not have any knowledge about the characteristics of the pumps and pannels they have at their disposal. The brands 
of the pumps installed in these areas are mainly Lorentz, CNP, LIKOU (Larens), JUQIANG, Grundfos, Asaman (Figure 11).

The most visible pumps brands at the farmers' level are the Lorentz and CNP brands. In fact, $44.1 \%$ of the pumps installed are Lorentz brands and $11.9 \%$ are CNP brands. The greater use of Lorentz brands is linked to the fact that farmers consider the Lorentz brand to be of better quality. In addition, many farmers have received their pumps as part of the project of diffusion of solar irrigation pumps in the Niayes which is supported by a company that are selling Lorentz pump brands. Asaman brands account for $8.5 \%$ of the pumps used by farmers. LIKOU (Larens) and Grundfos brands represent $6.8 \%$ and $3.4 \%$ of the pumps respectively, and the JUQIANG brand account for $1.7 \%$ of the pumps. However, $10 \%$ of the pumps brands were not identified. The characteristics of these pumps vary widely. Thus, solar pumping systems are installed with different materials and therefore with highly variable prices (Table 4). Also, Grundfos brand pumps used by farmers in Gabar village were installed in a test project, which meant that farmers received them free of charge.

Table 3 has shown that pumps installed in the northern Niayes area, more precisely in the Potou area are essentially submersible pumps. They have flow rates ranging from 5.2 to $25 \mathrm{~m}^{3} / \mathrm{h}$, pressures varying between 30 and $85 \mathrm{~m}$ and

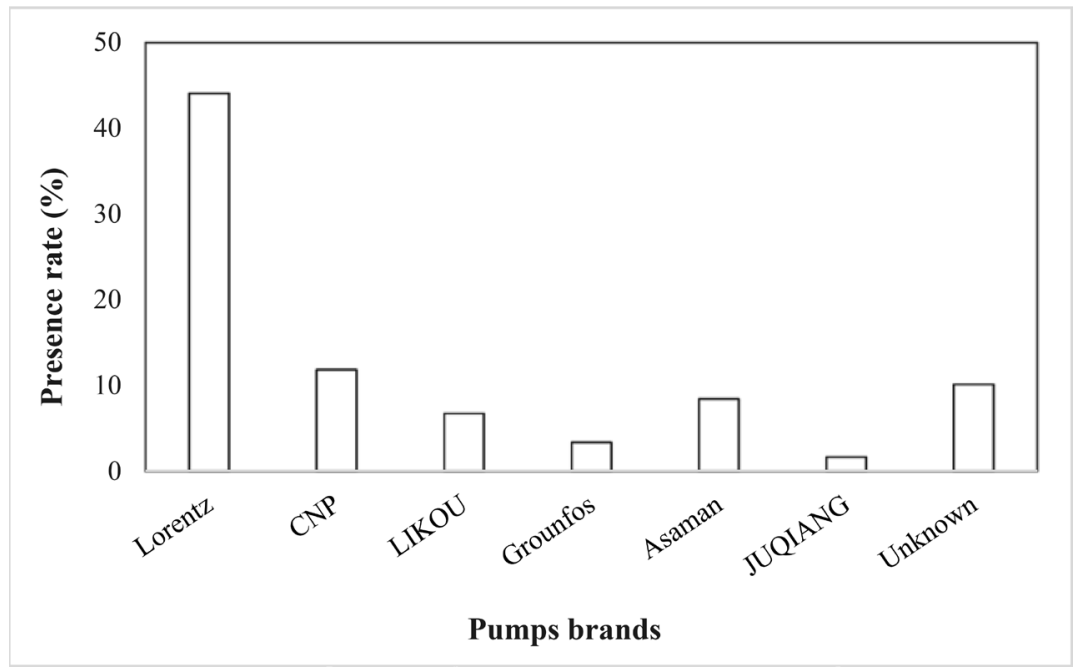

Figure 11. Pumps brands used by farmers.

Table 4. Characteristics of pumps and panels used by farmers in Potou area.

\begin{tabular}{cccccccc}
\hline & Lorentz & CNP & LIKOU & Asaman & Unknown & JUQIANG & Unknown \\
\hline Pump type & Submerged & Submerged & Submerged & Submerged & Submerged & Submerged & Submerged \\
Flow rate & $13 \mathrm{~m}^{3} / \mathrm{h}$ & $8-10 \mathrm{~m}^{3} / \mathrm{h}$ & $6.5-25 \mathrm{~m}^{3} / \mathrm{h}$ & $13 \mathrm{~m}^{3} / \mathrm{h}$ & $25 \mathrm{~m}^{3} / \mathrm{h}$ & $6.5 \mathrm{~m}^{3} / \mathrm{h}$ & $5.2 \mathrm{~m}^{3} / \mathrm{h}$ \\
Pressure & $40 \mathrm{~m}$ & $39-59 \mathrm{~m}$ & $30-85 \mathrm{~m}$ & $50 \mathrm{~m}$ & $40 \mathrm{~m}$ & 50 & 40 \\
Pump power & $1.8 \mathrm{~kW}$ & $1.5-2.2 \mathrm{~kW}$ & $1.5-2.2 \mathrm{~kW}$ & $1.5 \mathrm{~kW}$ & $2.2 \mathrm{~kW}$ & $0.75 \mathrm{~kW}$ & $2.2 \mathrm{~kW}$ \\
Pannels type & Polycrystalline & Polycrystalline & Polycrystalline & Polycrystalline & Polycrystalline & Polycrystalline & Amorphous \\
Pannels power & $270 \mathrm{~W}$ & $250 \mathrm{~W}$ & $250-300 \mathrm{~W}$ & $250-260 \mathrm{~W}$ & $250-300 \mathrm{~W}$ & $250 \mathrm{~W}$ & $200 \mathrm{~W}$ \\
\hline
\end{tabular}


powers that essentially are between $1.5 \mathrm{~kW}$ and $2.2 \mathrm{~kW}$. Also, $96 \%$ of the panels are made of polycrystalline silicon and only $40 \%$ is amorphous. Panels made of polycrystalline silicon have power ratings of 250 to $300 \mathrm{~W}$. In fact, the rarity of using amorphous panels can be explained by the fact that the price of polycrystalline panels is very profitable, and its output is higher than that of amorphous panels. This efficiency is estimated at $15 \%$ for polycrystalline crystals and $7 \%$ for amorphous crystals [12].

In addition, for the most part, farmers remain unaware of the unit prices of solar pumping system components. They discuss with companies or private individuals that provide and install the pumping systems. According to farmers, the investment cost of solar irrigation pump is very high. In fact, the investment cost required to install a solar pumping system in the Niayes area varies between 1372.04 euros (900,000 CFA) and 5488.17 euros $(3,600,000$ CFA). With the exception of CNP brand pumps, the investment cost of Chinese solar irrigation pumps does not exceed 3311.23 euros $(2,500,000 \mathrm{CFA})$. This result is similar to that of Abric (2019) on solar irrigation pumps in the Niaye region. The investment cost of CNP and Lorentz pumps is higher. It varies between 3262.41 euros $(2,140,000 \mathrm{CFA})$ and 5488.17 euros $(3,600,000 \mathrm{CFA})$. In addition, the costs of the solar irrigation pumps resulting from the diffusion project, which are estimated at $5488.17 €$ (CFA 3,600,000) actually exceed this price. Indeed, most of the farmers are financed by banks. Thus, these pumps, in reality, cost $6402.86 €$ $(4,200,000 \mathrm{CFA})$, payable over a period of 3 years. This happens in most cases. However, despite this, farmers consider that the use of solar irrigation pumps is more economical compared to the use of diesel pumps which were mainly used. In fact, they estimate that each year on average 1986.18 euros $(1,302,847$ CFA) are spent with regard to diesel used for irrigation on an average area of $1.3 \mathrm{ha}$ for a season with an average duration of 8 months. Thus, they are no longer dependent on fuel with the solar-powered irrigation pumps.

Moreover, knowing the significant contribution of the Niayes area in Senegalese agriculture, the government can make an effort to subsidize farmers in this area. These subsidies will allow them to easily access to solar-powered irrigation pumps. Therefore, this could allow the development of irrigated agriculture in the Niaye zone and shift production in the direction of self-sufficiency.

\subsubsection{Performance of Solar of Solar Irrigation Pumps in the Niayes Area} According to farmers, solar irrigation pumps are very efficient and thus allow farmers to meet crop irrigation water requirements. In fact, $84 \%$ of the pumps operate between 8 am and $6 \mathrm{pm}$, which corresponds to an operating time of 10 hours.

\section{1) Factors affecting pumps operation}

Solar irrigation pumps operation in the Niayes area is often affected by factors such as iron and low water tables' discharge. $50 \%$ of the wells are affected by iron and $2 \%$ are impacted by the low water table discharge. For some farmers, iron does not have a great impact on pumps at this stage. However, for others, iron 
has a negative effect on pumps. It adheres to the pumps, clogs them and consequently reduces the flow rate. Iron is the major factor that negatively affects solar irrigation pumps in the Niayes area.

\section{2) Maximum and minimum flow rate}

Not all farmers are familiar with the variation in flow rate of solar irrigation pumps. $32 \%$ of farmers do not have knowledge about the variation of the flow rate of solar irrigation pumps. For some of them, this is due to the fact that solar irrigation pumps are very recently installed and for others, it is due to the fact that the pumps have always high flow rates that allow them to satisfy their needs. Thus, for $68 \%$ of the farmers, the flow rate of solar irrigation pumps varies from one period to another during the year.

The results of the surveys show that the peak period of solar irrigation pump flow is between May and April. However, the flow rate of solar irrigation pumps is lower between December and February. This is due to the variation in sunshine during the year. In Saint-Louis region, the lowest average daily irradiation values range from 4.72 to $4.97 \mathrm{kWh} / \mathrm{m}^{2} /$ day. They are recorded between January and December. On the other hand, the maximum average daily irradiation values vary between 6.28 and $7.27 \mathrm{kWh} / \mathrm{m}^{2} /$ day and occur between March and July (RETScreen Expert). Indeed, in a solar pumping system, the electrical energy used to operate the pump is generated by the photovoltaic panels. The production of electricity in a solar system occurs at the level of the solar photovoltaic cells [3], which directly convert sunlight into electricity through the semiconductor material [13]. The PV panels are connected to a motor (DC or AC) that converts the electrical energy supplied by the PV panel into mechanical energy which is converted into hydraulic energy by the pump [2]. This result confirms that of [14] which shows that the direct current produced by solar photovoltaic cells is a function of the total incident solar irradiation.

\section{3) Maintenance of solar irrigation pumps}

The maintenance of solar pumping systems is not always carried out by farmers. Indeed, the solar panels are flooded every two or three days and even every day during dusty periods. However, not all pumps are maintained as such by farmers.

The results show that in the Potou area, $70 \%$ of farmers do not perform pump maintenance. In this case, pumps are only repaired when there is a failure. Pumps are repaired free of charge by the company that installed them if failure occurs during the warranty period, which varies from 1 to 5 years depending on the company. After the warranty period, farmers usually employ electricians or technicians to repair the pump. However, only $30 \%$ of farmers perform pump maintenance after installation. Maintenance is carried out every 2 to 4 months for the most part. But for other farmers the maintenance is done once a year. Maintenance is mainly carried out by the companies that installed the pumps. Farmers who benefit from maintenance are always under warranty. Also, it was observed that some farmers perform pump maintenance themselves. In this case, 
the maintenance consists of taking out the pump and cleaning the outside part with detergent or adding bleach in the mini-drillings.

In addition, for $96 \%$ of farmers, training on pump maintenance would be appreciated. Indeed, training will enable them to better maintain the pumps to avoid breakdowns. Also, it will allow them to avoid damage that is often caused by the time that companies take to come for pump reparation.

\section{Conclusion}

This study focused on the baseline of the use of solar irrigation pumps in the Niayes area. Surveys were conducted among twelve (12) suppliers and ten (10) service providers located in Dakar, Saint-Louis, Thies, and Louga regions and also among users of solar irrigation pumps located in ten (10) villages in the Potou area. Results show that there are a wide range of pump brands and characteristics on the market. These pumps have flow rates, pressures and powers that vary between $2.5 \mathrm{~m}^{3} / \mathrm{h}$ and $45 \mathrm{~m}^{3} / \mathrm{h}, 15 \mathrm{~m}$ to $160 \mathrm{~m}$ and $0.072 \mathrm{~kW}$ and $10 \mathrm{~kW}$, respectively. Most of the pumps are of Chinese brand. However, the Lorentz and Grundfos pumps are respectively German and Danish. Lorentz pumps have the highest cost compared to other pump brands. The installation costs vary depending on the number of panels to be installed and the location where the pump must be installed. The cost of maintenance is free of charge during the warranty period. However, this price varies between 152.5 euros and 457.4 euros/year. In order to farmers, it be would be interesting to carry out a more in-depth study on the technical and economic feasibility of using solar energy in irrigation in the Niayes region.

\section{Acknowledgements}

Sincere thanks to the WAGRINNOVA project (the Co-innovation across scales to enhance sustainable intensification, resilience $\&$ food, and nutritional security in water-managed agricultural systems in West Africa project) with all its partners including the UGB, CIHEAM BARI, CSIC, IRD, and CIRAD.

\section{Conflicts of Interest}

The authors declare no conflicts of interest regarding the publication of this paper.

\section{References}

[1] Lorenzo, C., Almeida, R.H., Martínez-Núnez, M., Narvarte, L. and Carrasco, L.M. (2019) Economic Assessment of Large Power Photovoltaic Irrigation Systems in the ECOWAS Region. Energy, 155, 992-1003. https://doi.org/10.1016/j.energy.2018.05.066

[2] Chandel, S.S., Naik, M.N. and Chandel, R. (2015) Review of Solar Photovoltaic Water Pumping System Technology for Irrigation and Community Drinking Water Supplies. Renewable and Sustainable Energy Reviews, 49, 1084-1099. https://doi.org/10.1016/j.rser.2015.04.083 
[3] Agrawal, S. and Jain, A. (2018) Financing Solar for Irrigation in India Risks, Challenges, and Solutions. Council on Energy, Environment and Water, New Delhi.

[4] Aguilar, L.A. (2015) Feasibility Study of Developing Large Scale Solar PV Project in Ghana: An Economical Analysis. Master of Science, Department of Energy and Environment Division, Electric Power Engineering Chalmers, Gothenburg.

[5] Hartung, H. and Pluschke, L. (2018) The Benefits and Risks of Solar-Powered Irrigation-A Global Overview. The Food and Agriculture Organization of the United Nations and Deutsche Gesellschaft für Internationale Zusammenarbeit.

[6] Fthenakis, V., Mason, J.E. and Zweibel, K. (2009) The Technical, Geographical, and Economic Feasibility for Solar Energy to Supply the Energy Needs of the US. Energy Policy, 37, 387-399. https://doi.org/10.1016/j.enpol.2008.08.011

[7] Ravikumar, D.V., Sudesh, R.K., John, J.C.M., Kumar, K.D. and Vinupal, P. (2019) Solar Power Based Water Pumping System with Automatic Irrigation Using Wireless Technology. International Journal of Advanced Research in Electrical, Electronics and Instrumentation Engineering, 8, 880-886.

[8] Abric, S. (2019) Solutions de pompage solaire pour l'irrigation à des profondeurs intermédiaires pour les petits producteurs de la région des Niayes. PRACTICA Foundation

[9] Wade, C.T. (2010) Réseau de transport et commercialisation de l'oignon dans les Niayes sur la grande Côte du Sénégal.

[10] GET.invest. (2019) Senegal: Renewable Energy in Agricultural Value Chains. Model Business Case: Solar Photovoltaic Water Pumping for Small-Scale Irrigation Scheme with Low Water Demand.

[11] Damme, M.V. and Sautrot, S. (2006) Etude comparative de panneaux solaires photo-voltaïques.

[12] Lal, S., Kumar, P. and Rajora, R. (2013) Performance Analysis of Photovoltaic Based Submersible Water Pump. International Journal of Engineering and Technology (IJET), 5, 552-560.

[13] Bhatia, S.C. (2014) Solar Divices. In: Bhatia, S.C., Ed., Advanced Renewable Energy Systems, Elsevier, Amsterdam, 68-93.

https://doi.org/10.1016/B978-1-78242-269-3.50003-6

[14] Fesharaki, V.J., Dehghani, M., Fesharaki, J.J. and Tavasoli, H. (2011) The Effect of Temperature on Photovoltaic Cell Efficiency. Proceedings of the 1st International Conference on Emerging Trends in Energy Conservation, Tehran, 20-21 November 2011, 20-21. 